\title{
Activation and Habituation of Extracellular Signal-Regulated Kinase Phosphorylation in Zebra Finch Auditory Forebrain during Song Presentation
}

\author{
Hui-Yun Cheng ${ }^{1}$ and David F. Clayton ${ }^{1,2}$ \\ ${ }^{1}$ Department of Cell and Structural Biology and ${ }^{2}$ Beckman Institute, University of Illinois, Urbana, Illinois 61801
}

\begin{abstract}
The sound of tape-recorded birdsong triggers a set of behavioral and physiological responses in zebra finches, including transcriptional activation of the zenk gene in the auditory forebrain. Song repetition leads to the stimulus-specific habituation of these responses. To gain insight into the mechanisms that couple auditory experience to gene regulation, we monitored the phosphorylation of the zebra finch extracellular signal-regulated kinase (ERK) protein by immunoblotting. Initial presentations of novel song (but not tones or noise) resulted in a rapid increase in ERK phosphorylation, followed by a return to basal levels within $5 \mathrm{~min}$. This response was localized to the auditory forebrain where the zenk gene is activated. Sustained repetition of one song caused a selective habituation of the ERK response: a different song triggered another cycle of ERK phosphorylation without altering the habituated response to the first. To test directly for a role of ERK in experience-dependent zenk gene regulation, we infused an inhibitor of mitogen-activated and extracellular-regulated protein kinase kinase (MEK-1; the enzyme responsible for ERK activation) unilaterally into one auditory lobule just before song stimulation. The song-induced increase in zenk mRNA was blocked on the side of the injection, but not on the contralateral (uninfused) side. These results show that ERK phosphorylation is necessary for the initiation of the zenk gene response to novel song and identify ERK as a plausible site of signal integration underlying the selective habituation of genomic responses to a repeated song.
\end{abstract}

Key words: auditory; habituation; kinase; forebrain; song; transcription; transduction

\section{Introduction}

Changes in neuronal gene transcription have a role in the regulation of memory formation (Clayton, 2000; Athos et al., 2002; Bozon et al., 2002; Guzowski, 2002; Ressler et al., 2002). How does a particular sensory or behavioral experience lead to transcriptional activation in a particular set of neurons? In songbirds, initial exposure to tape-recorded birdsong triggers a transient wave of expression in the auditory forebrain of immediate early genes (IEGs); the most-studied example is the gene known as zenk (Mello et al., 1992; Mello and Clayton, 1994; Mello, 2002). This effect is correlated with development of behavioral memory for the specific song stimulus (Stripling et al., 2003). Of particular interest, the IEG response to a particular song can vary, depending on recent exposure and the context of presentation. When a particular song has been repeated appropriately, the IEG response to that song habituates. It can be reactivated when a novel song is presented (Mello et al., 1995) or even when the repeated song is presented from a new position in space (Kruse, 2001).

What cellular mechanisms underlie the activation and habit-

\footnotetext{
Received April 14, 2004; revised July 16, 2004; accepted July 20, 2004.

This work was supported by Public Health Service Grant 5 R01 MH52086. For help and advice we thank Telsa Mittelmeier, Roy Stripling, Amy Kruse, Graham Huesmann, and Shu Dong.

Correspondence should be addressed to Dr. David F. Clayton, Department of Cell and Structural Biology, B107 Chemical and Life Sciences Laboratories, University of Illinois, 601 South Goodwin Avenue, Urbana, IL 61801. E-mail: dclayton@uiuc.edu.

DOI:10.1523/JNEUROSCI.1405-04.2004

Copyright $\odot 2004$ Society for Neuroscience $\quad 0270-6474 / 04 / 247503-11 \$ 15.00 / 0$
}

uation of zenk transcription by a song stimulus? Based on an analysis of the zenk gene promoter (see Fig. 1) and precedents in other model organisms, a central role has been hypothesized for the intracellular signaling protein, extracellular signal-regulated kinase (ERK). ERK (a MAP kinase) can phosphorylate transcription factors that bind to regulatory elements common in IEG promoters. Known targets of ERK regulation include the Elk-1 transcription factor, which binds to the Ets site in DNA, and cAMP response element-binding (CREB) family proteins, which bind to the CRE site (Sgambato et al., 1998; Davis et al., 2000, 2003). Both Elk-1 and CREB have been implicated in learning (Impey et al., 1998; Sgambato et al., 1998; Swank, 2000; Sananbenesi et al., 2002; Bozon et al., 2003). ERK itself has been shown to be a key component in the experience-dependent activation of brain gene expression in a number of models of learning and memory (Adams and Sweatt, 2002), including long-term potentiation (LTP) (English and Sweatt, 1996, 1997), fear conditioning (Atkins et al., 1998; Schafe et al., 2000), spatial memory (Blum et al., 1999), conditioned taste aversion (Berman et al., 1998), and (in invertebrates) classical conditioning and sensitization (Crow et al., 1998; Sharma et al., 2003). The kinase activity of ERK is regulated by dual phosphorylation of a specific pair of tyrosine and threonine residues (Boulton et al., 1991; Seger et al., 1991), which can be assessed by using phosphorylation-specific antibodies.

Here, we describe experiments to test the hypothesis that ERK activation is involved centrally in experience-dependent regula- 
tion of zenk gene transcription in the zebra finch auditory forebrain. We show that initial song presentations trigger a sharp increase in ERK phosphorylation. This ERK response habituates with specific song repetition, and this habituation is both persistent and quite specific for an individual song. Finally, we show (by directed intracerebral injection of an ERK pathway inhibitor) that ERK activation is necessary for the expression of zenk after song stimulation.

\section{Materials and Methods}

Reagents. Monoclonal diphospho-ERK ( $\mathrm{Thr}^{202} / \mathrm{Tyr}^{204}$ in human ERKI) and polyclonal ERK antibodies, horseradish peroxidase (HRP)-conjugated anti-rabbit IgG, and U0126 were purchased from Cell Signaling Technology (Beverly, MA). Polyclonal cyclophilin antibody was obtained from Upstate Biotechnology (Lake Placid, NY). Sheep HRP-conjugated anti-mouse whole antibody and an enhanced chemiluminescence (ECL) kit were from Amersham Biosciences (Buckingshamshire, UK). All other chemicals were of analytical grade or the highest grade available.

DNA sequence analysis. Using the original canary zenk cDNA as a probe (Mello et al., 1992), we cloned a 5' overlapping fragment of canary genomic DNA and sequenced it with standard techniques (GenBank accession number AY562554). Presence of conserved binding site motifs for transcription factors was assessed by using the TFSEARCH web interface at GenomeNet (http://www.cbrc.jp/research/db/TFSEARCH.html) for searching the TFMATRIX database of transcription binding sites (release 3.3). High-scoring binding sites for $>15$ factors were detected in the 790 nucleotides 5 ' to the transcription start site; here we focused on binding sites known to be conserved in the promoter of the gene ortholog in other species and implicated in neural plasticity (see Fig. 1).

Animals. All experiments were performed under protocols approved by the University of Illinois Laboratory Animal Care Advisory Committee. Adult male zebra finches (at least $90 \mathrm{~d}$ old) were bred and raised in an aviary of Beckman Institute animal facility or purchased from vendors (Magnolia Bird Farm, Anaheim, CA). They were housed three in a cage ( $35.6 \mathrm{~cm}$ long $\times 40.6 \mathrm{~cm}$ wide $\times 45.7 \mathrm{~cm}$ high) before their use. All birds were kept on a $12 \mathrm{hr}$ light/dark cycle. Each experiment started with the overnight isolation of a single bird in a smaller cage $(30.5 \mathrm{~cm}$ long $\times 22.9$ $\mathrm{cm}$ wide $\times 40.6 \mathrm{~cm}$ high) placed inside a sound-attenuation chamber (Tracor Instruments, Austin, TX). An incandescent lamp (40 W) was placed in the chamber to maintain the light/dark cycle of the animal quarters. The next day between 2:00 P.M. and 5:00 P.M. the acoustic stimuli were played back through a speaker (Radio Shack) located in the chamber. The average sound intensity was adjusted to $70 \mathrm{~dB}$ via a sound pressure meter (Radio Shack). After the sound playback interval (see below), the animal was decapitated, and the brain was dissected as follows.

Operational definition and dissection of auditory lobule. Both genomic and electrophysiological responses to song are most evident in the most caudal and medial portions of the nidopallium and mesopallium (under the old nomenclature, NCM and CMHV) (Reiner et al., 2004). Although this song-responsive subregion has well defined dorsal, ventral, anterior, posterior, and medial boundaries, it does not have a well defined lateral border, and it surrounds the primary auditory thalamorecipient area of the telencephalon (Field L2a) in which genomic responses to song have not been observed (Mello and Clayton, 1995). For the biochemical analyses performed here, we needed to be able to dissect this song-responsive region from unstained, unfixed tissue, and the dissection needed to be as rapid and reproducible as possible. In pilot studies we found that, in fresh zebra finch brains bisected down the midline, we readily could observe by eye the ventricular boundaries of the songresponsive area (Mello and Clayton, 1994); we also found that a single lobe-like unit (wet weight, $\sim 1 \mathrm{mg}$ ) could be removed, seemingly intact, by manual dissection by using a fine scalpel to peel away overlying hippocampus and sever connections to more medial tissue at a depth of 1-2 mm. Using quantitative RT-PCR, we confirmed that increases in zenk mRNA of appropriate magnitude could be detected in RNA extracts prepared from this tissue in birds exposed to song compared with quiet controls (data not shown). Because this dissection is defined operation- ally and contains partial elements of several formal anatomical regions, we refer to it here by the term auditory lobule $(\mathrm{AL})$. The AL dissection is most enriched for the primary zenk-responsive portion of the caudomedial nidopallium (NCM), but it also contains some amount of zenkresponsive caudomedial mesopallium (CMM) and nonresponsive Field L2a. For protein extraction and immunoblotting the tissue was quickfrozen in ethanol/dry-ice bath. Whole brain was collected in O.C.T. compound for in situ hybridization. The frozen tissue was stored at $-80^{\circ} \mathrm{C}$ until processed.

Auditory stimuli. Songs used in this study were obtained from birds bred and raised at The Ohio State University by Dr. Susan Volman. Synthetic stimuli were prepared by Dr. Roy Stripling, using customdesigned software (C.-Y. Yen, R. A. Mauck, and S. F. Volman). All stimuli were presented by using the personal computer software Syrinx developed by Dr. John Burt. In these experiments we organized the song stimuli in two different ways for two different purposes. In those situations in which the goal was to give the strongest possible stimulus to facilitate detection of any ERK response (see Figs. 3-5), we used the "triple-song" organization, shown previously to be especially effective at eliciting a zenk response in a large majority of neurons in NCM (Mello et al., 1992) and resulting in a significant increase in zenk expression even after a single presentation (Kruse et al., 2000). The triple-song stimulus design contains a $15 \mathrm{sec}$ block of three different song bouts (each lasting $\sim 5 \mathrm{sec}$ ) and played back to back, followed by $45 \mathrm{sec}$ of silence. A bird hearing two presentations of triple song (see Figs. 3-5) thus hears $15 \mathrm{sec}$ of sound (three songs in a row), $45 \mathrm{sec}$ of silence, and then another $15 \mathrm{sec}$ of sound (the three songs in a row again), for a total of $30 \mathrm{sec}$ of acoustic stimulation over a total elapsed time of $75 \mathrm{sec}$ from stimulus onset. Because we had no previous information about the timing or sensitivity of a possible ERK response to song, in our first stimulation experiment (see Fig. 3 ) the birds were killed after increasing numbers of block repetitions $(2,30,60$, or $90 \times)$ simply to scan for an optimal stimulation-anddeath time point.

In those situations in which the goal was to obtain more regular temporal control over the stimulus/response period and selectively habituate the response to a single song (see Figs. 6-10), we used a "single-song" stimulus design in which a single iteration of one song ( $2 \mathrm{sec}$ in duration) was repeated once every $10 \mathrm{sec}$. Thus, eight presentations of song A in the single-song organization (see Figs. 4, 6-7, "A8") lasts for $72 \mathrm{sec}$ from the first song onset to the final song offset and approximately matches the elapsed time of two repetitions of triple song but has less acoustic stimulation and complexity. In experiments 8 and 9 we used 10 repetitions of single song ("A10") as the basic unit of stimulation, following a previous demonstration that this generates a near-maximal level of zenk mRNA measured 30 min later (Kruse et al., 2000). In Figure 4 the tone stimulus consisted of a sequence of ascending tones ranging from 1 to $7 \mathrm{kHz}$ in which each tone lasted $300 \mathrm{msec}$, with a $20 \mathrm{msec}$ rise and fall time and $110 \mathrm{msec}$ intertone interval. The computer-generated white noise burst was $2.05 \mathrm{sec}$ long, with a $40 \mathrm{msec}$ rise and fall time. The presentation rates of the tone and white noise bursts matched those of the single song (i.e., once every $10 \mathrm{sec}$ ). Although we did not record the birds' behavioral responses to the auditory presentations formally, in general they conformed to the responses documented previously (Stripling et al., 2003). On occasion some birds did sing in response to song stimuli, but we did not exclude these subjects from the present experiments; previous studies have suggested that the song a bird hears himself sing has only a modest effect on molecular responses in NCM (Jarvis and Nottebohm, 1997).

Surgery and microinjection. Birds were anesthetized with 3-4 ml/kg of a pentobarbital/chloral hydrate mixture similar in composition to Equithesin $\left(2.12 \% \mathrm{w} / \mathrm{v} \mathrm{MgSO}_{4}, 10 \% \mathrm{v} / \mathrm{v}\right.$ ethanol, $39.1 \% \mathrm{v} / \mathrm{v}$ propylene glycol, $0.98 \% \mathrm{w} / \mathrm{v}$ sodium pentobarbitone, $4.2 \% \mathrm{w} / \mathrm{v}$ chloral hydrate), restrained with a cloth jacket, and placed in a stereotaxic apparatus $(\mathrm{H}$. Adams, Caltech Central Engineering, Pasadena, CA) with the horizontal head axis $35^{\circ}$ relative to the vertical axis of the instrument. A small circle of the skull was removed, and an opening was cut in dura $50 \mu \mathrm{m}$ lateral and $70 \mu \mathrm{m}$ anterior to $\mathrm{Y}_{0}$, centered over the region of the greatest zenk response to song (Mello and Clayton, 1994); a pre-cut (2 mm length) 26G guide cannula (Plastics One, Roanoke, VA) was implanted. A 33G dummy cannula was inserted to prevent tissue clog. The cannulas were 
fixed at the skull with dental cement (Grip Cement, LD Caulk, Milford, $\mathrm{DE})$. After surgery each bird was isolated individually in an acousticattenuation chamber overnight for recovery and then was transferred back to animal quarters for $6-7 \mathrm{~d}$ before the drug injection was performed. The afternoon before microinjection the bird was transferred to the acoustic-attenuation chamber for overnight isolation. Immediately before injection the dummy cannula was removed from the guide cannula and replaced with a $33 \mathrm{G}$ internal cannula, which was connected via PE20 tubing to a Hamilton microsyringe driven by a microinfusion pump (KD Scientific, New Hope, PA). Microinjection was performed unilaterally in $0.5 \mu \mathrm{l}$ volume, delivered over $5 \mathrm{~min}$, of the selective ERK pathway inhibitor U0126 (10 $\mu \mathrm{g} / \mu \mathrm{l}$ in DMSO; Cell Signaling Technology). Pilot studies with fluorescent markers indicated that this volume represents a satisfactory compromise between filling the AL and avoiding excessive spread into other brain regions. The injection cannula was left in position for an additional $1 \mathrm{~min}$ before withdrawal to minimize dragging of the injected liquid along the injection tract. The no-drug control groups in Figure 10 (silence and song) were not cannulated.

Protein extract preparation and immunoblot analysis. The AL from each bird (dissected and frozen as described above) was placed in $60 \mu \mathrm{l}$ of buffer A [containing (in mM): 10 HEPES, pH 7.9, $10 \mathrm{KCl}, 1.5 \mathrm{MgCl}_{2}, 0.5$ DTT, 0.5 PMSF, $0.5 \mathrm{NaF}, 0.5 \mathrm{Na}_{3} \mathrm{VO}_{4}$, plus $5 \mu \mathrm{M}$ microcystin, $20 \mu \mathrm{M}$ cyclosporin, and $4 \mu \mathrm{l} / \mathrm{ml}$ protease inhibitor mixture (Sigma, St. Louis, $\mathrm{MO})$ ] and was homogenized by Pellet Pestle (Kontes, Vineland, NJ). Supernatant (cytosolic fraction) was collected by centrifuging the homogenates at $5000 \times g$ for $10 \mathrm{~min}$. The pellet was resuspended in $15 \mu \mathrm{l}$ of buffer B [containing (in mM): 20 HEPES, pH 7.9, $400 \mathrm{NaCl}, 0.2$ EDTA, 0.5 DTT, 0.5 PMSF, $0.5 \mathrm{NaF}, 0.5 \mathrm{Na}_{3} \mathrm{VO}_{4}$, plus $20 \%$ glycerol (v/v), $5 \mu \mathrm{M}$ microcystin, $20 \mu \mathrm{M}$ cyclosporin, and $4 \mu \mathrm{l} / \mathrm{ml}$ protease inhibitor mixture] and incubated on a shaker for $30 \mathrm{~min}$ at $4^{\circ} \mathrm{C}$. The nuclear fraction was collected as the supernatant after $30 \mathrm{~min}$ of centrifugation at $14,000 \times g$ at $4^{\circ} \mathrm{C}$. The whole-cell extract was reconstituted as an equal ratio of cytosolic and nuclear fractions. Concentration was determined by BCA protein concentration assay (Pierce, Rockford, IL). An equal volume of $2 \times$ SDS loading buffer (10\% glycerol, $5 \% \beta$-mercaptoethanol, $2.3 \%$ SDS, and $62.5 \mathrm{~mm}$ Tris- $\mathrm{HCl}, \mathrm{pH}$ 6.8) was added to the protein extract and boiled for $5 \mathrm{~min}$ (loading samples). Loading samples were aliquoted and stored at $-80^{\circ} \mathrm{C}$ until immunoblot analysis. Equal amounts of protein (12-20 $\mu \mathrm{g})$ were subjected to the SDS-PAGE (12\% polyacrylamide) and Western blot analysis. The blots were blocked with $5 \%$ nonfat dry milk in TBS-T (20 mm Tris, pH 7.6, $137 \mathrm{~mm} \mathrm{NaCl,} \mathrm{0.1 \%} \mathrm{Tween} \mathrm{20)} \mathrm{for} 1 \mathrm{hr}$ at room temperature and probed with primary antibody at $4^{\circ} \mathrm{C}$ overnight. Subsequently, the blots were incubated with HRP-conjugated secondary antibody for $1 \mathrm{hr}$ at room temperature before reaction with ECL substrate and exposure to $\mathrm{x}$-ray films. The blots usually were cut at $\sim 30 \mathrm{kDa}$ marker; the upper portion was probed with phospho-ERK antibody ( $1000 \times$ dilution in $1 \%$ nonfat dry milk in TBS-T), and the lower portion was probed with cyclophilin antibody $(2000 \times$ dilution in 5\% nonfat dry milk in TBS-T). Intensity of each signal in the $\mathrm{x}$-ray films was measured by NIH Image 1.62 (National Institutes of Health, Bethesda, MD). Cyclophilin is a constitutively expressed peptidyl-prolyl isomerase that acts as a housekeeping protein in the cell, and its intensity was used to normalize the pERK signal across the different samples on the same blot.

In situ hybridization. The $10 \mu \mathrm{m}$ parasagittal slices were prepared in a cryostat and mounted on aminopropyltriethoxysilane-treated slides. After fixation in $3 \%$ paraformaldehyde and dehydration the slides were stored at $-80^{\circ} \mathrm{C}$ until the time for in situ hybridization. The method for in situ hybridization to access the zenk expression with digoxigenin is the same as reported in a previous work (Jin and Clayton, 1997). The level of zenk expression in each bird was measured by counting the density of positive-labeled cells in the Microcomputer Controlled Imaging Device system (Imaging Research, St. Catharines, Ontario, Canada), as described by Stripling et al. (2001). Briefly, the threshold for measuring positive labeling was set by reference to the overlying hippocampus, which has a uniformly low staining for zenk regardless of song exposure. With the use of the outline tool the range of pixel values within the hippocampal area was displayed as a histogram. The 99th percentile in this histogram was set as the threshold at which density values would be considered above background for labeling in NCM/CMM. Two size cri-

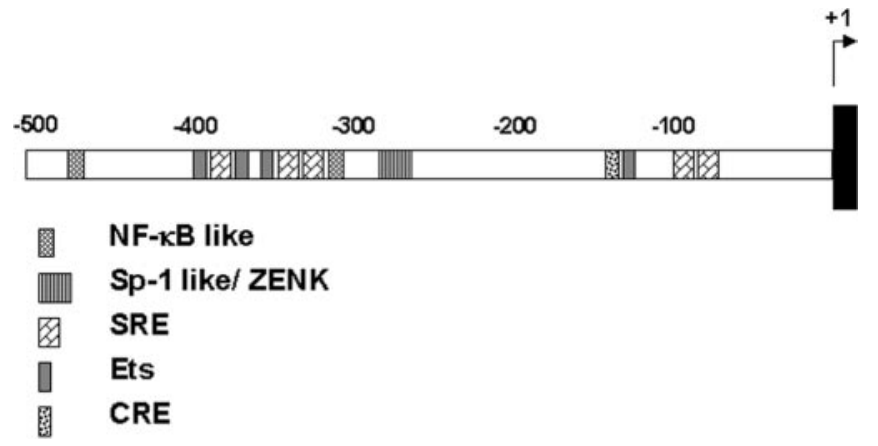

Figure 1. The songbird (canary) zenk promoter. The diagram shows the location of consensus binding sites for several transcription factors of interest relative to the start site $(+1)$; similar binding sites are conserved in mammalian orthologs of the gene (Changelian et al., 1989).

teria also were incorporated so that the minimum target size was $>30$ $\mu \mathrm{m}^{2}$, and the average mean size was $130-180 \mu \mathrm{m}^{2}$.

Statistics. Overall effect in each experiment was determined by oneway ANOVA, using the general linear modeling procedure in the Statistical Analysis System software package. The response variable for immunoblotting is the cyclophilin-adjusted pERK intensities; for in situ hybridization it is the zenk-positive cell density. The criterion of significance was set at 0.05 . If the significance for overall effect reached 0.05 , the post hoc pairwise analysis would be performed. Post hoc pairwise comparison was performed by Dunnett's $t$ test compared with the silence control group, except as specially noted.

\section{Results}

\section{Detection of zebra finch ERK and pERK}

To gain insight into possible mechanisms of zenk gene regulation, we first determined the sequence of the 5 ' flanking region of the songbird zenk gene (Fig. 1). We noted the presence of putative binding sites for several transcription factors also present in mammalian zenk gene orthologs, including Ets and CRE, which bind proteins known to be regulated by ERK (see Introduction). To investigate the possible role of a zebra finch ERK ortholog in neural responses to song, we began by preparing protein extracts from the auditory lobule (AL; see Materials and Methods) of zebra finch brains. The extracts were electrophoresed, blotted, and immunostained by using a well characterized monoclonal antibody specific for the active phosphorylated form of ERK or a polyclonal antibody to total ERK protein (Fig. 2). A control extract from HEK-293 (human embryonic kidney-293) cells was included as a reference on the blots. Both antibodies detected two bands in the HEK-293 extracts, as expected, representing the two mammalian forms of ERK (ERKI, $\sim 44 \mathrm{kDa}$; ERKII, $\sim 42 \mathrm{kDa}$ ). In the zebra finch extract, each antibody detected only a single band of intermediate size at $\sim 43 \mathrm{kDa}$. This suggests that there may be only one ERK isoform expressed in the zebra finch (see Discussion).

\section{Brief song exposure triggers ERK phosphorylation in auditory forebrain}

To determine whether ERK phosphorylation is increased in the AL under conditions that lead to zenk gene induction, we stimulated birds with tape-recorded birdsong and performed the immunoblotting procedure as shown in Figure 2, quantifying relative pERK signal intensity by normalizing to the signal for a control protein (cyclophilin) measured in the same lane. We observed a significant increase in ERK phosphorylation in the birds hearing song compared with those hearing only silence (Fig. 3) $\left(F_{(4,14)}=5.46 ; p<0.01\right)$. The increase was greatest when 


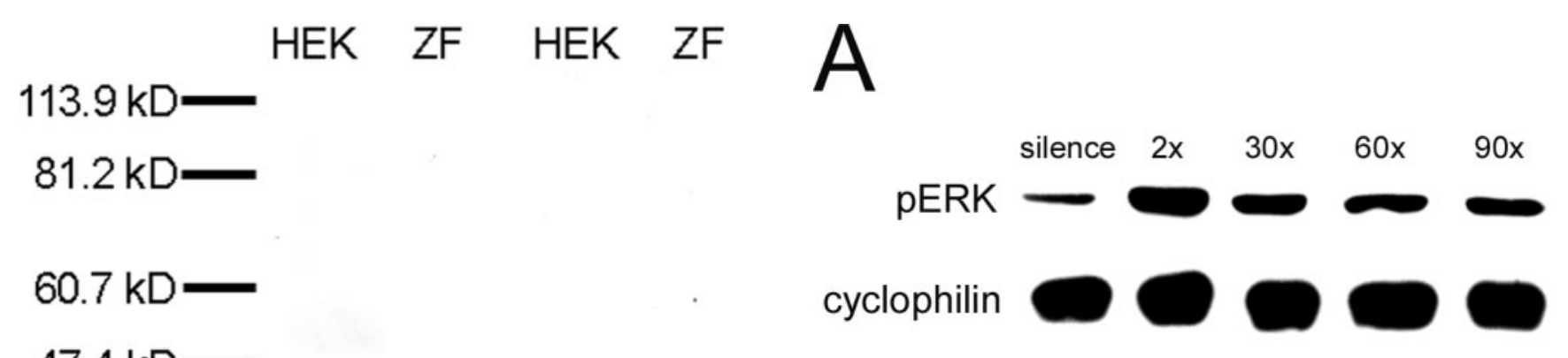

\section{$47.4 \mathrm{kD}-$}

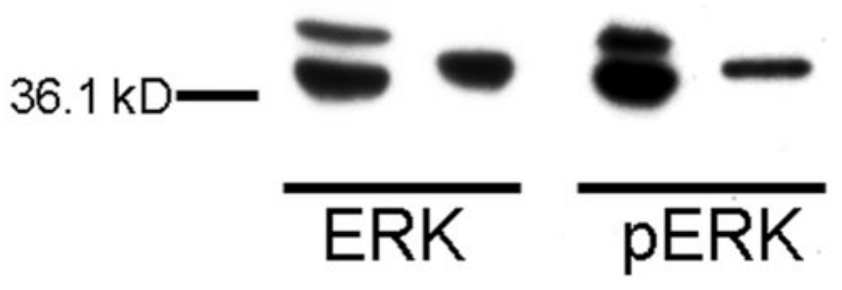

Figure 2. Commercial ERK and pERK antibodies recognize a zebra finch protein. Shown are representative immunoblots of HEK-293 (HEK) and zebra finch AL extracts (ZF) probed with commercial ERK (left) and pERK (right) antibodies, with size standards as indicated. HEK-293 extracts contain two species recognized by the antibodies, as expected (42 and $44 \mathrm{kDa}$ ); however, only one protein band in zebra finch AL is recognized by these antibodies.

measured immediately after just two block presentations, or $\sim 75$ sec from stimulus onset ( post hoc pairwise comparison, $p<$ 0.005). After 30 min of stimulation the ERK phosphorylation had subsided to a level not statistically different from the silence control $(p=0.195$ for $30 \times, 0.393$ for $60 \times$, and 0.365 for $90 \times$, respectively).

To evaluate the stimulus specificity of the pERK response in the AL, we compared the pERK levels from birds exposed to different stimulation procedures (Fig. 4): two consecutive presentations of the triple-song stimulus or repetition of a single song for a similar duration (see Materials and Methods) or matched presentations of either a tone sequence or a white noise stimulus as used in previous zenk response studies (Mello et al., 1992; Park and Clayton, 2002). One-way ANOVA of the results shows a significant effect of stimulus type on ERK phosphorylation $\left(F_{(4,39)}=4.99 ; p<0.005\right)$. Post hoc pairwise comparison with the silence controls (Dunnett's $t$ test) suggests that both types of song stimulation induced ERK phosphorylation significantly ( $p=0.002$ and $p=0.013$ for triple song and single song, respectively), whereas the tone and noise stimuli did not trigger a significant increase in pERK ( $p=0.861$ and 0.669 , respectively) (Fig. 4). Thus, ERK phosphorylation in the AL shows the same general specificity for birdsong as that observed for zenk gene expression.

To determine whether ERK phosphorylation by song playback occurs specifically in the auditory forebrain where the zenk response is localized, we performed the experiment shown in Figure 5. Male zebra finches were presented with two repetitions of the triple-song stimulus as in Figures 3 and 4, and tissue was collected immediately from five brain regions (AL, anterior forebrain, cerebellum, hippocampus, and optic tectum). Whole-cell extracts were immunoblotted with both pERK and ERK, and the signal intensities were normalized to the value for the AL from silence controls on the same blot. Again as in previous experiments, pERK levels increased several-fold in song-stimulated birds compared with silence controls (Fig. $5 C)(p<0.05$, Student's $t$ test). A much smaller increase $(\sim 40 \%)$ also was detected
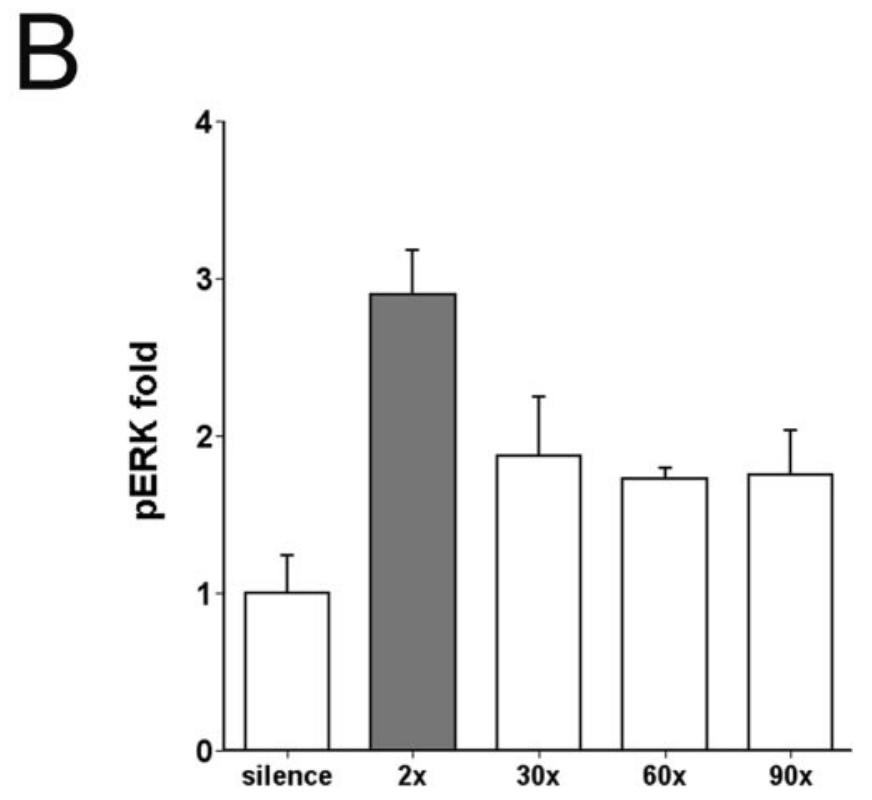

Figure 3. ERK phosphorylation is induced by song playback in zebra finch. $A$, Representative immunoblots of zebra finch AL extracts probed with pERK-specific and cyclophilin antibodies; the cyclophilin immunoreactivity was used to correct for possible loading differences in different lanes. AL was collected from birds immediately after exposure to two repetitions (lasting 75 $\mathrm{sec}), 30 \times(\sim 30 \mathrm{~min}), 60 \times(\sim 60 \mathrm{~min})$, and $90 \times(\sim 90 \mathrm{~min})$ of song playback. $B$, Group data of corrected pERK signal in AL from birds exposed to $2 \times(n=5), 30 \times(n=4), 60 \times(n=3)$, and $90 \times(n=3)$ song repetitions, shown as fold increase relative to average intensities of corrected pERK in controls exposed to silence $(n=4)$. Error bars represent SEM. The gray fill identifies the only group statistically significant from the silence controls ( $p<0.05$, one-way ANOVA and post hoc Dunnett's $t$ test). Note that the pERK signal was increased immediately after just two repetitions of the song stimulus.

in hippocampus $(p<0.05)$, but no significant change was observed in the other three regions. Interestingly, we also noted significant regional variations in the level of ERK phosphorylation in the silence control birds $\left(F_{(4,10)}=8.2 ; p<0.005\right)$, implying that ERK is activated differentially in different brain systems even in an animal at rest. Total ERK protein levels were similar in all brain regions $\left(F_{(4,25)}=1.79 ; p=0.16\right)$ and were not affected significantly by song exposure (vs silence controls, $p=0.872$ ).

In the next experiment we evaluated how long ERK phosphorylation is sustained once stimulation ceases. For this experiment and the ones that follow, we shifted to the simpler single-song presentation scheme introduced in Figure 4 in which a single song $(2 \mathrm{sec})$ was repeated every $10 \mathrm{sec}$ for eight times $(\sim 72 \mathrm{sec})$. The AL was collected immediately ( $0 \mathrm{~min}$ ) or at $5,15,30$, or 60 min after the last presentation for immunoblot analysis (Fig. 6). Once again, there was a significant overall effect of song exposure on ERK phosphorylation in the $\operatorname{AL}\left(F_{(5,28)}=7.46 ; p<0.001\right)$. In paired comparisons with the silence control, a significant increase in pERK was present only in the tissue collected immedi- 
A

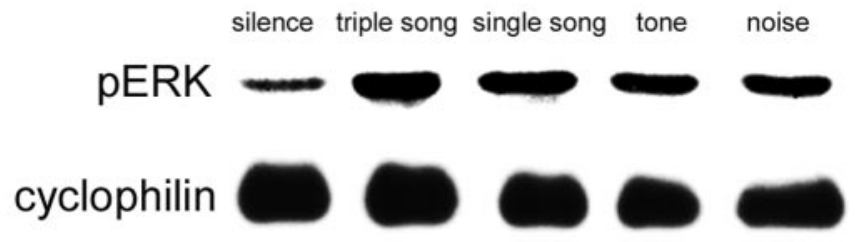

B

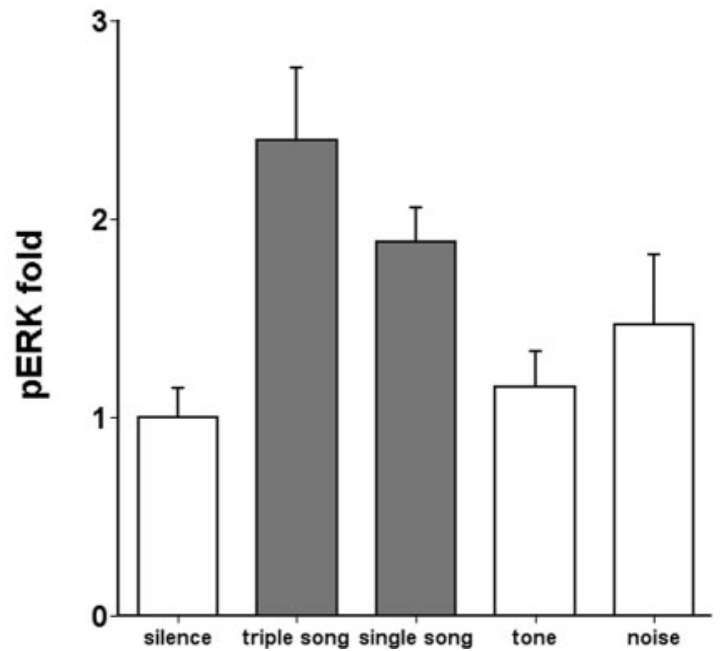

Figure 4. Stimulus specificity of ERK phosphorylation. A, Representative immunoblots of zebra finch AL extracts probed with pERK-specific and cyclophilin antibodies as in previous figures. Birds were exposed to two repetitions of a stimulus made from three different songs (triple song, described in Materials and Methods) or eight repetitions of one song (single song) or eight repetitions of either ascending tones or white noise over a period of $72-75$ sec and then were killed immediately. $B$, Group data of corrected pERK signal in AL from birds exposed to triple song $(n=7)$, single song $(n=7)$, tone $(n=10)$, and noise $(n=9)$ shown as fold increase relative to average intensities of corrected $p$ ERK in silence control $(n=12)$. Gray fill indicates the two groups with statistically significant differences from the silence controls $(p<$ 0.05 , one-way ANOVA and Dunnett's $t$ test in comparison to the silence group). Error bars represent SEM.

ately after the song playback ( $p<0.001)$, and pERK had returned to basal levels by $5 \mathrm{~min}(p=0.996)$.

\section{Stimulus-specific habituation of ERK phosphorylation}

After a single song has been repeated for $1-3 \mathrm{hr}$, zenk mRNA levels have returned to baseline; subsequent presentations no longer induce a zenk response, but the same cells apparently mount a full response when a new stimulus is introduced (Mello and Clayton, 1995; Kruse, 2001) (see also Stripling et al., 1997). In Figure 7 we tested whether the ERK phosphorylation response also habituates after prolonged stimulus repetition, as described by Mello and Clayton (1995). Birds were habituated to one song by repeating it for $2.5 \mathrm{hr}$ (single-song presentation design, $2 \mathrm{sec}$ "song A" every $10 \mathrm{sec}$ for a total of 908 repetitions) (Fig. 7, designated $\left.\mathrm{A}_{908}\right)$. Controls included birds hearing only the initial eight repetitions $\left(A_{8}\right)$ and birds hearing only silence. The average intensity of pERK in the AL from the habituated birds $\left(\mathrm{A}_{908}\right)$ was not significantly different from that of the silence controls $(p>$ 0.99 ). However, when habituated birds then were exposed briefly to a novel song $B\left(A_{900} B_{8}\right)$, pERK immediately increased to a level
A

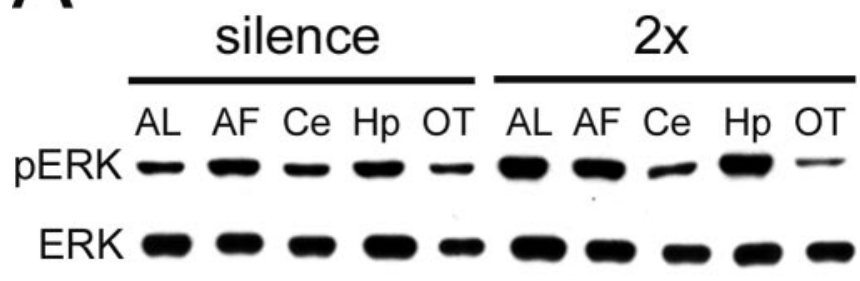

B
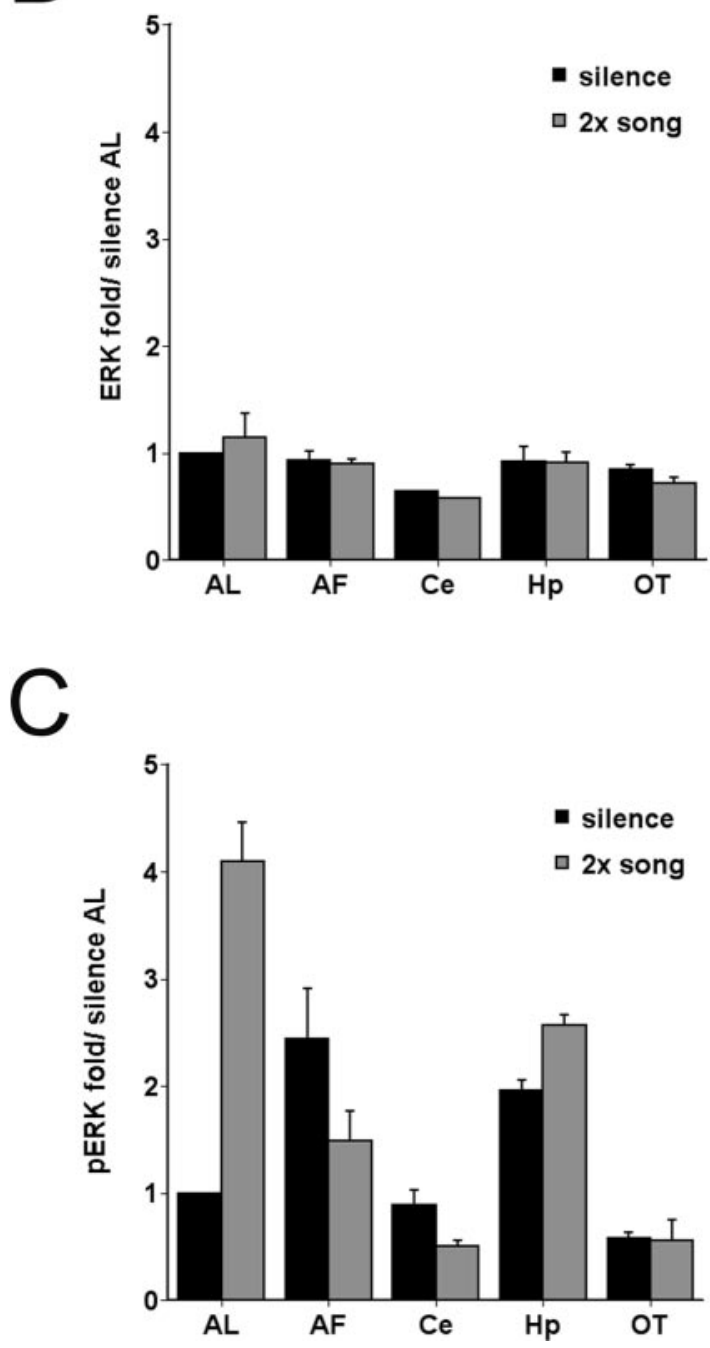

Figure 5. Anatomical localization of pERK increase. $A$, Representative immunoblots of extracts from $A L$, anterior forebrain (AF), cerebellum (Ce), hippocampus (Hp), and optic tectum (OT) of birds exposed to silence or two repetitions of triple song, probed with pERK and ERK antibodies. $B$, Mean intensity of ERK signal in brain regions as in $A$, normalized to intensity in $\mathrm{AL}$ from silence controls; birds were exposed to silence or song ( $n=3$ for each group). C, Mean intensity of pERK signal in brain regions as in $A$, normalized to intensity in AL from silence controls for birds exposed to silence or song ( $n=3$ for each group). Note that song stimulation induces a large increase in pERK only in AL. Error bars represent SEM.

that was equivalent to that in birds hearing a song for the first time and significantly greater than the level in the silence controls ( $p<0.05$ for comparing either $\mathrm{A}_{8}$ or $\mathrm{A}_{900} \mathrm{~B}_{8}$ birds with silence controls). Thus, ERK phosphorylation, like zenk expression, is specifically sensitive to stimulus novelty. 
A

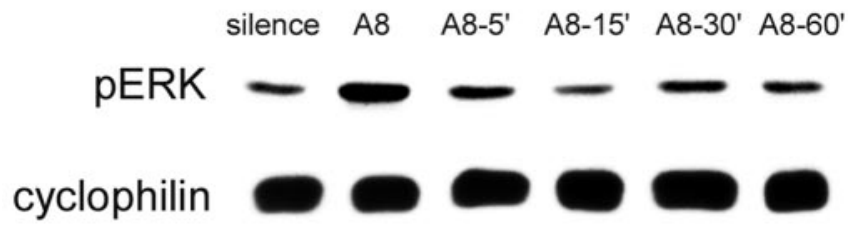

A

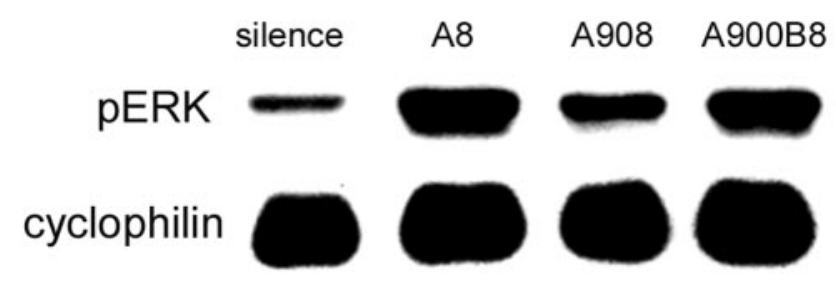

B

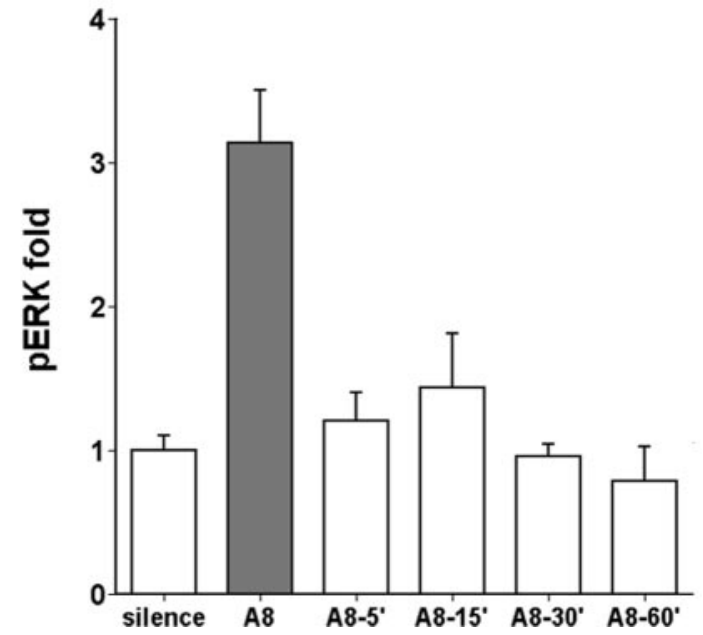

Figure 6. Transient induction of ERK phosphorylation. $A$, Representative immunoblots of zebra finch AL extracts probed with pERK-specific and cyclophilin antibodies. Birds were exposed either to silence or to eight repetitions of a single song over $72 \sec (A 8)$ and then were killed for collection either immediately or after $5 \mathrm{~min}$ (A8-5'), $15 \mathrm{~min}$ (A8-15'), $30 \mathrm{~min}$ (A8$\left.30^{\prime}\right)$, or $60 \mathrm{~min}\left(\mathrm{A8}-60^{\prime}\right)$ in silence. $B$, Group data from birds under conditions $\mathrm{A} 8(n=7), \mathrm{A} 8-5^{\prime}$ $(n=6), \mathrm{A} 8-15^{\prime}(n=6), \mathrm{A} 8-30^{\prime}(n=4)$, and A8-60' $(n=3)$ shown as fold increase relative to average intensities of corrected pERK in silence control $(n=8)$. Gray fill indicates the group with a statistically significant difference from the silence controls ( $p<0.05$, one-way ANOVA and Dunnett's $t$ test in comparison to the silence group). Error bars represent SEM.

Habituation of ERK phosphorylation implies the formation of some sort of memory of the repeated song. This memory must serve as a reference point for discrimination of a different song as novel in comparison. It does not necessarily have to persist beyond the immediate period of repetitive stimulation, however. For example, the bird simply may stop attending to any repetitive stimulus without forming an explicit stable memory of the particular stimulus. To see whether the habituation memory persists beyond the period of immediate stimulation, we performed the experiment in Figure 8. The training stimulus was repeated for 200 trials ( $33 \mathrm{~min}$ ), but this was followed by a period of silence before presentation of the test stimulus. For example, Figure 8, lane $3\left(\mathrm{~A}_{200} 60^{\prime}-\mathrm{A}_{10}\right)$, shows the immunoblot result from birds who heard song $A$ for 200 trials, then 60 min of silence, and then 10 trials of song $A$ as the test stimulus before death. When the test stimulus was the same as used in the training period, there was no significant increase in ERK phosphorylation relative to the silence controls $\left(p>0.99, \mathrm{~A}_{200} 60^{\prime}-\mathrm{A}_{10} ; p=0.88, \mathrm{~A}_{200} 5^{\prime}-\mathrm{A}_{10}\right)$. When the test stimulus was different from the training stimulus, however, ERK phosphorylation increased again $\left(p<0.005, \mathrm{~A}_{200} 5^{\prime}-\right.$ $B_{10}$ ). Thus, the lack of responsiveness to a particular stimulus can persist selectively for at least $1 \mathrm{hr}$ after a $30 \mathrm{~min}$ training period.

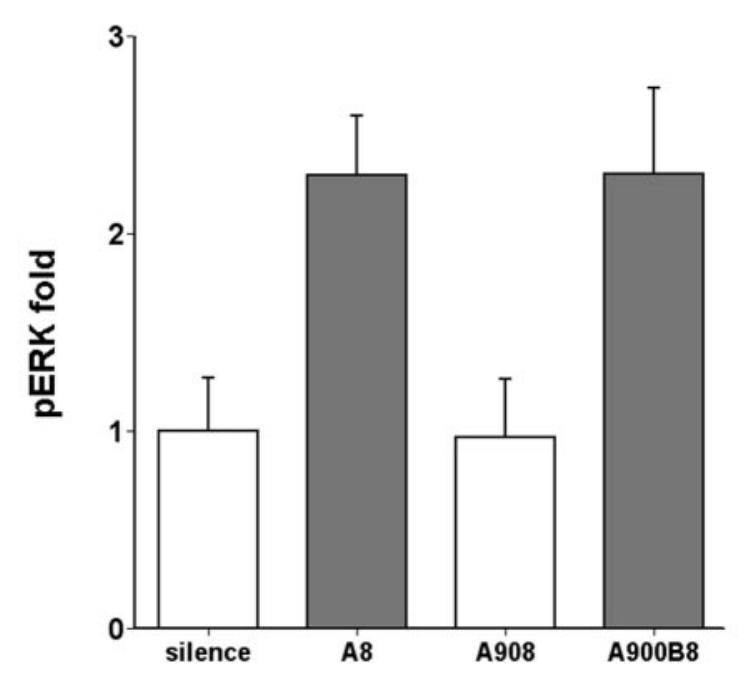

Figure 7. pERK is habituated by repeated playback. $A$, Representative immunoblots of zebra finch AL extracts probed with pERK-specific and cyclophilin antibodies as in previous figures. AL was collected from birds exposed to eight (A8) or $908 \times$ (A908) repetitions of a single song or to 900 repetitions of one song, followed by eight repetitions of a different song (A900B8). B, Group data of corrected pERK signal in AL from birds under conditions A8 $(n=8), A 908(n=6)$, and A900B8 $(n=6)$ shown as fold increase relative to average intensities of corrected pERK in silence controls $(n=8)$. Gray fill indicates statistically significant difference from silence controls $(p<0.05$, one-way ANOVA and Dunnett's $t$ test). Note that extended song repetition (A908) led to suppression of $p E R K$, but brief exposure to a novel song then reactivated $p E R K$ phosphorylation (A900B8). Error bars represent SEM.

We performed one additional, even more stringent test of the specificity and stability of the memory evident in habituation of ERK activity (Fig. 9). The goal here was to determine whether the bird truly discriminates a particular habituated song, even when that song is encountered as part of a more complex series of experiences. Birds were first exposed sequentially to two different songs ( $\mathrm{A}$ and $\mathrm{B}$ ) for 10 trials. They were then presented a third song (C) for 200 repetitions to habituate the response to that song, as in Figure 8. Next they heard 10 trials of song A once again, followed by a 5 min period of silence. Finally, as the test stimulus immediately before death, the birds heard either the training song (C) or song B. We imagined three possible outcomes. If neither B nor $C$ activated ERK in the final test, then we would conclude that the habituation memory was not actually specific for the repeated song $(\mathrm{C})$; perhaps the bird simply stopped paying attention after the long sequence of changing song exposures. Conversely, if both $\mathrm{B}$ and $\mathrm{C}$ activated ERK, we would conclude that the brief exposure to song A immediately before the final test aroused the bird, again implying the operation of a general attentional mechanism and not a specific, selective memory. The actual result, 
A

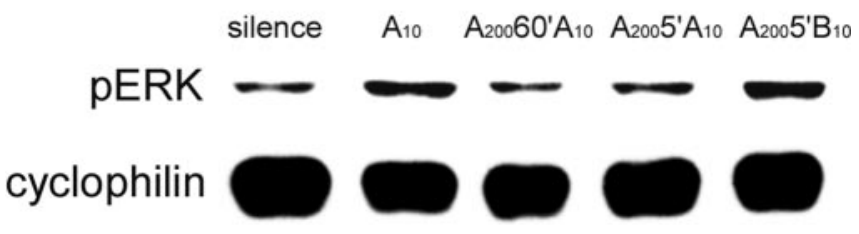

B

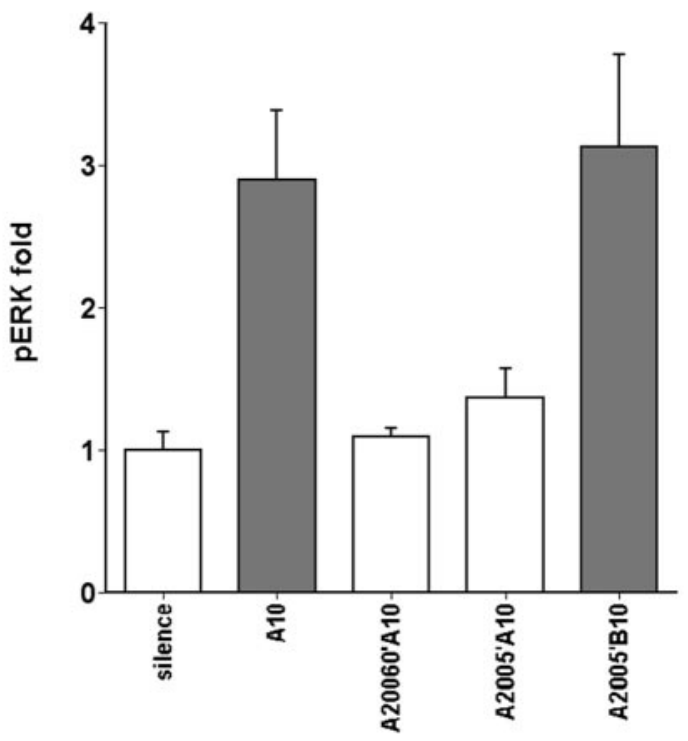

Figure 8. pERK habituation is maintained after periods of silence. $A$, Representative immunoblots of zebra finch AL extracts probed with pERK-specific and cyclophilin antibodies. The nomenclature indicates the sequence of exposures to song or silence before death, as follows: $A_{10}$ (killed immediately after 10 repetitions of song A), $A_{200} 60^{\prime} A_{10}$ (200 repetitions of $A$, followed by 60 min of silence, and then 10 more repetitions of $A$ ), $A_{200} 5^{\prime} A_{10}$ (200 repetitions of song $A$, followed by 5 min of silence, and then 10 more repetitions of $A$ ), $A_{200} 5^{\prime} B_{10}$ (200 repetitions of song $A$, followed by 5 min of silence, and then 10 more repetitions of a novel song, B). $B$, Mean corrected data for $p E R K$ in AL from birds under conditions $A_{10}(n=6), A_{200} 60^{\prime} A_{10}$ $(n=4), A_{200} 5^{\prime} A_{10}(n=5)$, and $A_{200} 5^{\prime} B_{10}(n=4)$, shown as fold increase relative to average intensities of corrected pERK in silence controls $(n=6)$. Gray fill indicates statistically significant difference from silence controls ( $p<0.05$, one-way ANOVA and Dunnett's $t$ test). Note that habituation to song $A$ persisted after intervening periods of silence $\left(A_{200} 60^{\prime} A_{10}\right.$, $\left.A_{200} 5^{\prime} A_{10}\right)$, but exposure to a new song reactivated ERK $\left(A_{200} 5^{\prime} B_{10}\right)$. Error bars represent SEM.

however, was that the training song $\mathrm{C}$ remained habituated after the intervening exposure to song $\mathrm{A}\left(\mathrm{ABC}_{200} \mathrm{~A} 5^{\prime}-\mathrm{C} ; p=0.99\right.$ vs silence controls), yet song $\mathrm{B}$ triggered a new wave of ERK activation $\left(\mathrm{ABC}_{200} \mathrm{~A} 5^{\prime}-\mathrm{B} ; p<0.001\right)$. Thus, the memory evident in pERK habituation is specific for the repeated stimulus; it excludes other songs heard only briefly in the same general time period and persists despite intervening distracters or periods of silence.

\section{Necessity of ERK activation for zenk induction}

The experiments in Figures 3-9 clearly show that ERK phosphorylation increases transiently in auditory forebrain in response to song stimuli and that the response can undergo highly selective habituation indicative of some form of song memory. The timing and selectivity of the response are consistent with the hypothesis that ERK regulates the zenk gene response to songs. As a direct test of this hypothesis, we used the selective ERK pathway inhib-
A

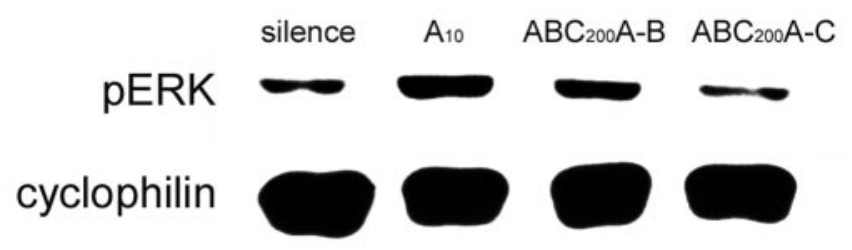

B

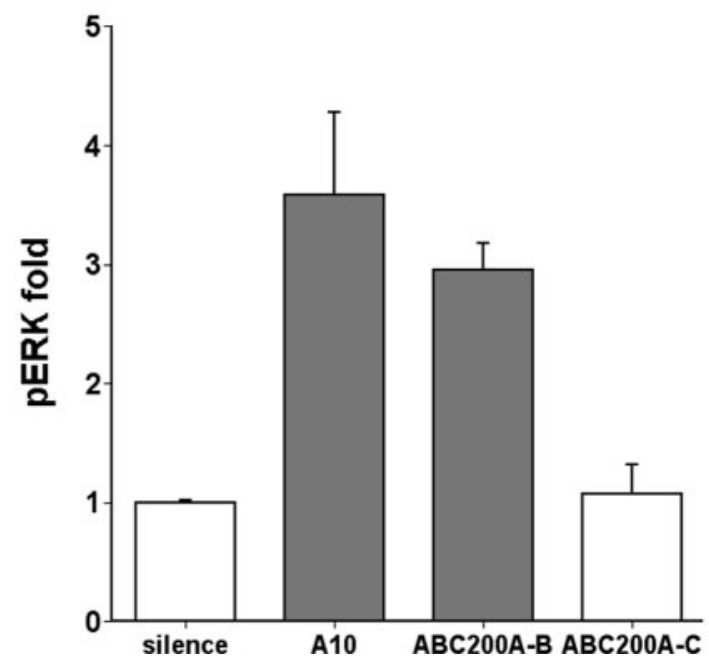

Figure 9. Song-specific pERK habituation is maintained after intervening exposure to a different song. Three different unfamiliar zebra finch songs (designated A, B, C) or silence (-) was used in the experiment, each presented in the single-song format ( 2 sec of song every 10 $\mathrm{sec})$. The nomenclature indicates the sequence of exposures as follows: $A_{10}, 10$ repetitions of song $A$, followed by immediate death; $A B C_{200} A-B, 10$ repetitions each of songs $A, B$, and $C$, followed by 200 repetitions to habituate song $C$, then 10 presentations of $A$, then 5 min of silence, and then a final exposure to 10 repetitions of song $B ; A B C{ }_{200} A-C$, same as $A B C{ }_{200} A-B$ except that the final exposure was to the habituated stimulus, song $C$. $A$, Representative immunoblots of zebra finch AL extracts probed with pERK-specific and cyclophilin antibodies. B, Mean corrected $\mathrm{pERK}$ signal intensity relative to silence control group; $n=3$ each group. Gray fill indicates statistically significant difference from silence controls ( $p<0.05$, one-way ANOVA and Dunnett's $t$ test). Note that after intervening exposure to song $A$ the response to song $C$ remained selectively habituated. Error bars represent SEM.

itor U0126 (Favata et al., 1998), which has been effective in studies of ERK in mammalian learning and memory (Schafe et al., 2000). Birds were prepared surgically under anesthesia with an intracerebral cannula directed at the $\mathrm{AL}$ and then were allowed to recover for 6-7 d. On the day of the experiment, U0126 was infused unilaterally into the left $\mathrm{AL}$ of awake, unanesthetized birds. The birds then were presented with tape-recorded birdsong as in the previous experiments. U0126 injection effectively suppressed ERK phosphorylation on the ipsilateral, but not the contralateral, side in birds hearing song playback (Fig. 10A), confirming its effectiveness as an inhibitor in this context. Figure $10 B$ demonstrates the effect of U0126 on zenk expression in a representative experiment. The staining intensity of zenk clearly is reduced in the drug-treated animal on the ipsilateral side (Fig. $10 \mathrm{Ba}$ ) compared with the contralateral side in the same animal (Fig. $10 B b$ ) or to the vehicle-only control animal (Fig. 10Bc,d). Quantitative group data (Fig. 10C) show robust induction of zenk that follows song after ipsilateral injection of the DMSO vehicle 
A
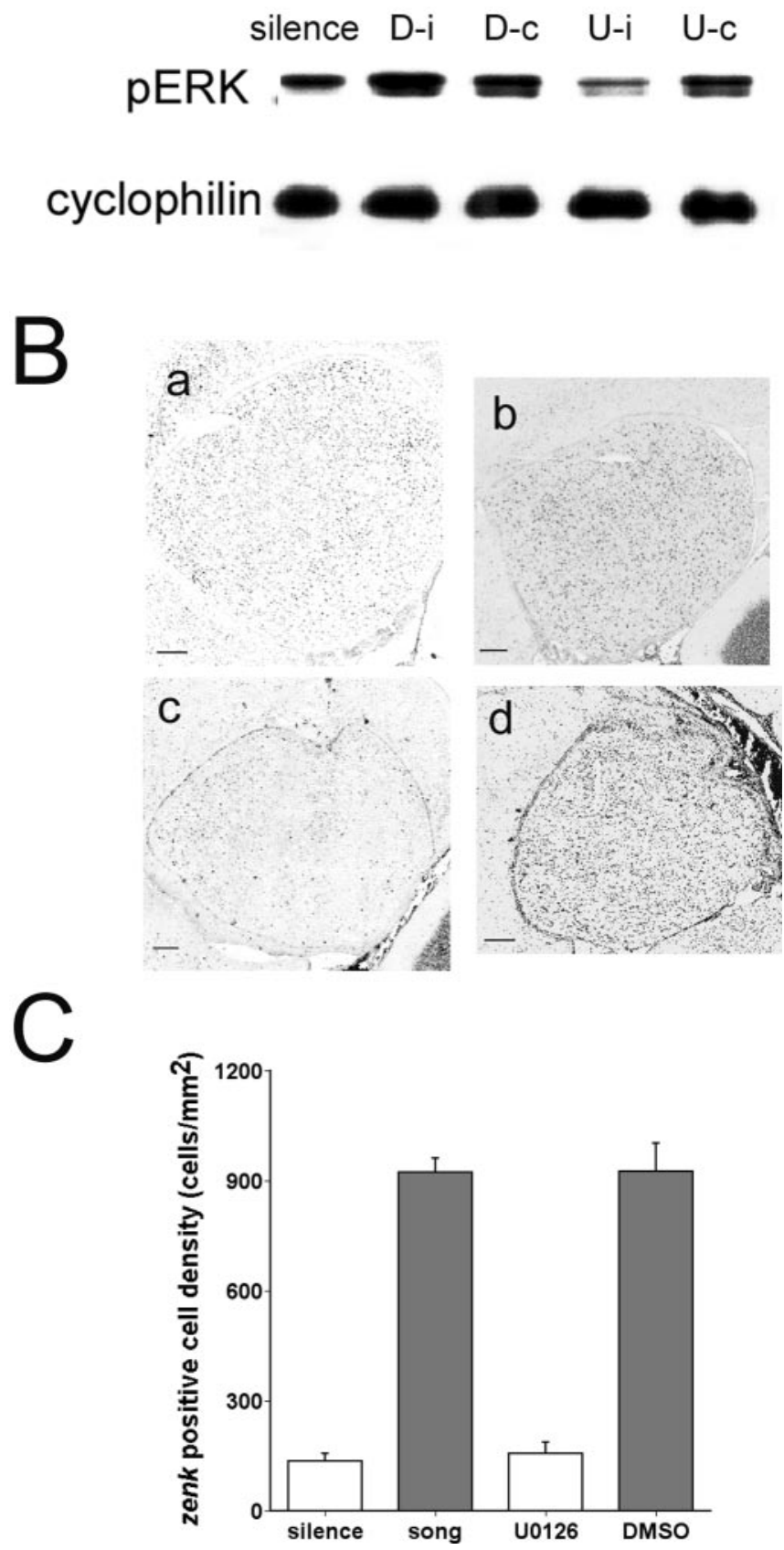

Figure 10. Inhibition of ERK phosphorylation inhibits zenk induction by song playback. $A$, Representative immunoblots showing suppression of song-induced pERK levels by unilateral AL-directed infusion of MEK-1 inhibitor U0126. At $1 \mathrm{hr}$ after infusion the birds were exposed to eight repetitions of single song playback and assayed for $p$ ERK and cyclophilin immunoreactivity in AL as in Figure 6 (group A8). D-i, AL ipsilateral to injection of DMSO vehicle; D-c, AL contralateral to injection of DMSO vehicle; U-i, AL ipsilateral to injection of U0126; U-c, AL contralateral to injection of U0126. $B$, Representative in situ hybridization images of zenk expression in zebra finch $A L$. $B a$, Silence control; $B b, 30$ min after novel song stimulation; $B C, 30$ min after novel song stimulation, ipsilateral side of U0126-injected brain; $B d, 30$ min after novel song stimulation, contralateral side of DMSO-injected brain. C, Mean zenk-positive cell counts in AL from birds exposed to silence $(n=4), 30$ min of song playback (song, $n=4$ ), ipsilateral DMSO injection followed by 30 min of song playback (DMSO, $n=4$ ), and ipsilateral U0126injection followed by 30 min of song playback (U0126, $n=4)$. Gray fill indicates statistically significant difference from silence controls ( $p<0.05$, one-way ANOVA and Dunnett's $t$ test). Note that zenk levels are increased in birds hearing song and in DMSO-injected controls, but not in U0126-injected birds, when compared with silence controls. Error bars represent SEM. alone ( $p<0.005$ in Dunnett's $t$ test relative to silence control). In contrast, injection of U0126 reduced the number of zenk-positive cells to a level that was not significantly above the silence control ( $p=0.167$, Dunnett's $t$ test).

\section{Discussion}

These results show that playback of tape-recorded birdsong induces rapid and transient ERK phosphorylation in zebra finches, specifically in the auditory telencephalon. Songs induce this response, but not tones or white noise. Stimulus repetition habituates the response without affecting the response to other songs. In these respects, ERK phosphorylation and zenk gene activation share the same patterns of specificity. However, the time course of ERK phosphorylation is advanced relative to zenk RNA and protein accumulation. Moreover, pharmacological inhibition of ERK phosphorylation suppresses the induction of zenk gene expression by novel song. These observations indicate that ERK activation is necessary for the zenk response to novel song and identify ERK as a possible upstream point of signal integration during the habituation of the genomic response to a repeated song.

This is the first report of ERK activity in a songbird. Three observations confirm that we measured ERK instead of other molecules. First, the same band (of appropriate size) is recognized by two different antibodies: one for ERK itself and the other for phosphorylated ERK (Fig. 2). Second, ERK phosphorylation is attenuated by AL-directed microinjection of the mitogenactivated and extracellular-regulated protein kinase kinase (MEK)-specific inhibitor U0126 (Fig. 10). However, unlike the situation in mammals in which there are two distinct but related forms of ERK (ERKI/II), we detected only a single protein band in the zebra finch with these antibodies. This finding is consistent with other evidence suggesting the presence of only a single ERK isoform, most similar to ERKII, in birds (Perron and Bixby, 1999). Current efforts to establish an expressed sequence tag (EST) database from zebra finch brain have identified a single ERK-like sequence, with 277/281 identical amino acids relative to human ERKII (contig387, http://titan.biotec.uiuc.edu/ songbird/).

Both ERK phosphorylation and zenk transcription are induced by exposure to only a few repetitions of a novel song. A key difference is that ERK phosphorylation peaks quickly and subsides after only a few minutes, whereas the zenk response follows a much slower and more prolonged trajectory. For pERK the maximal increase was detected in birds killed immediately at the end of a brief stimulation period; 5 min later the pERK levels were at baseline again (Fig. 6). Even with continued stimulation, the pERK levels had declined again significantly by $30 \mathrm{~min}$ (Fig. 3). In contrast, zenk RNA levels do not peak until 30-60 min after the onset of song stimulation (Mello and Clayton, 1994; Mello et al., 1995; Kruse et al., 2000). Increases in ZENK protein levels are delayed even more (Mello and Ribeiro, 1998; Kruse et al., 2000). These observations are consistent with the hypothesis that ERK activation marks the initiation of a sustained process of gene expression and protein synthesis, and ERK phosphorylation (by MEK-1) is a necessary step in this process. Once the process is set in motion, elevated ERK activity no longer is required for its completion.

The rapid time course of ERK activation also parallels another aspect of forebrain auditory physiology: modulation of electrophysiological spike rate. Neurons first fire rapidly in response to a new song stimulus, but the rate decreases during each subsequent 
presentation until a moderate asymptotic value is reached after 10-30 trials (Stripling et al., 1997). ERK activation itself could have a direct role in mediating a change in cellular excitability. For example, the membrane potassium channel also is regulated by ERK (Yuan et al., 2002), and this may alter membrane excitability directly (Selcher et al., 2003). Different pools of ERK apparently exist in the cell, some positioned to influence nuclear transcription and others more proximally involved in surface membrane function (Morozov et al., 2003). Alternatively, ERK activation and cellular spike rate may be regulated by common factors that coordinate different cell functions related to memory storage. Indeed, ERK activity has been found to be influenced by multiple neurotransmitter and second messenger pathways (Berman et al., 2000; Adams and Sweatt, 2002), and systemic injection of an $\alpha_{1}$-adrenergic inhibitor has been reported to block songinduced zenk expression in zebra finches (Ribeiro and Mello, 2000).

The brief time course of ERK activation observed here is somewhat unusual, but not without precedent in other systems. Indeed the time course of ERK activation seems to vary widely in different experimental contexts. In rodent hippocampus, for example, pERK phosphorylation has been detected immediately after a 10 min tetanus (Davis et al., 2000) or even within seconds of a foot shock (Alonso et al., 2002). The duration of pERK elevation has ranged from $<15 \mathrm{~min}$ (Davis et al., 2000) to as much as 1-3 hr (Izquierdo et al., 2001; Ying et al., 2002). In rat dorsal hippocampus the pERK increases within $5 \mathrm{~min}$ after multiple Morris water maze training and then returns to control level by 30 min (Blum et al., 1999). In insular cortex of rats drinking an unfamiliar taste, pERK elevation follows a slower time course, peaking only after $\sim 30 \mathrm{~min}$ (Berman et al., 1998). The response in amygdala to pavlovian fear conditioning is slower still, with no significant increase until $\sim 60 \mathrm{~min}$ (Schafe et al., 2000). A single ERK-like molecule also has been identified in Aplysia, and repeated tail shocks or pulses of serotonin cause prolonged increases in its phosphorylation over a period of several hours (Sharma et al., 2003). We also note in our experiments here that, when song stimulation was continued for 30-90 min, pERK levels did not necessarily return to baseline during the period of ongoing stimulation (Fig. 3). Although the prolonged apparent increase did not reach statistical significance in this experiment, the levels at $30-90 \times$ were also not statistically different from the maximum reached after $2 \times$ (Scheffe's post hoc test). Thus, we can conclude confidently that ERK phosphorylation reaches a maximum within minutes, but our evidence remains equivocal about how long an increase is sustained in the face of ongoing stimulation.

Interestingly, we also noticed significant regional differences in basal ERK phosphorylation in birds exposed only to silence, with relative elevations in anterior forebrain and hippocampus compared with other brain regions. Similar regional variations in basal zenk expression were not observed in previous studies. Indeed, the zenk level in hippocampus was low and stable enough to be used as the internal reference for nonspecific background (Stripling et al., 2001). This suggests that ERK phosphorylation by itself is not a simple linear predictor of zenk mRNA levels. Nevertheless, the acute increase in ERK phosphorylation that follows novel song exposure appears to be linked closely to subsequent zenk gene induction, a conclusion reinforced by the blocking effects of the MEK-1 inhibitor on the zenk response to novel song (Fig. 10).

The term "habituation" has been used to refer to many different phenomena (Thompson and Spencer, 1966) ranging from escape responses in crabs (Pereyra et al., 2000) or cellular properties in reduced Aplysia preparations (Stopfer et al., 1996) to attentional processes in human infants (Clifton and Nelson, 1976). We use the term advisedly here to describe the various changes that occur in songbirds as they listen to a repeated song, recognizing that all the many different phenomena of habituation do not necessarily share the same neural mechanism. In the experimental paradigm that has been used here, an individual bird is placed in overnight isolation and then abruptly experiences the sound of another zebra finch's song. The bird reacts visibly to this presentation by adopting a "listening" posture; with continued repetition of the same song from the same position in space, the duration of the listening response shortens dramatically (Stripling et al., 2003). These behavioral changes are correlated with changes in both gene expression and electrophysiological activity in the auditory lobule; now we also can add changes in ERK phosphorylation to the list. We find it especially interesting that song habituation (whether measuring ERK, zenk, spike rate, or listening behavior) is both stable and specific for a single stimulus. By all four measures the response habituates when one song is repeated. The data in Figures 8 and 9 demonstrate that ERK habituation represents specific song memory formation and not simply the animal's fatigue or generalized loss of interest, because the habituation is quite stable and specific for the repeated song across various testing paradigms. Presentation of a novel song will reactivate all of these measures without reversing the decreased response to the specific habituated song. Thus, it seems as if the system is being tuned actively to recognize, discriminate, and categorize specific stimuli.

Ethologically, this makes much sense. Adult songbirds respond to the sound of other birds' songs and may use these songs to recognize and discriminate among individuals (Stoddard, 1996; Zann, 1996). The fact that the habituated stimulus is picked from a sequence of songs might, in a reduced way, reflect the kind of experience a bird ordinarily has when encountering a new individual in a colony of familiar members. An important goal now is to address the underlying physiological mechanism responsible for modulation of ERK responses to auditory stimuli according to stimulus context and familiarity. One possibility is that the primary sensory drive onto the responding cells in the $\mathrm{AL}$ changes with experience. Another possibility is that neuromodulatory signals, associated with attention or other organismal variables, can regulate dynamically the biochemical response of auditory neurons to sensory drive. Whatever the modulatory mechanism, it may play a central role in regulating the way in which the brain stores selective memories of experience.

\section{References}

Adams JP, Sweatt JD (2002) Molecular psychology: roles for the ERK MAP kinase cascade in memory. Ann Rev Pharmacol Toxicol 42:135-163.

Alonso M, Viola H, Izquierdo I, Medina JH (2002) Aversive experiences are associated with a rapid and transient activation of ERKs in the rat hippocampus. Neurobiol Learn Mem 77:119-124.

Athos J, Impey S, Pineda VV, Chen X, Storm DR (2002) Hippocampal CREmediated gene expression is required for contextual memory formation. Nat Neurosci 5:1119-1120.

Atkins CM, Selcher JC, Petraitis JJ, Trzaskos JM, Sweatt JD (1998) The MAPK cascade is required for mammalian associative learning. Nat Neurosci 1:602-609.

Berman DE, Hazvi S, Rosenblum K, Seger R, Dudai Y (1998) Specific and differential activation of mitogen-activated protein kinase cascades by unfamiliar taste in the insular cortex of the behaving rat. J Neurosci 18:10037-10044. 
Berman DE, Hazvi S, Neduva V, Dudai Y (2000) The role of identified neurotransmitter systems in the response of insular cortex to unfamiliar taste: activation of ERK1-2 and formation of a memory trace. J Neurosci 20:7017-7023.

Blum S, Moore AN, Adams F, Dash PK (1999) A mitogen-activated protein kinase cascade in the CA1/CA2 subfield of the dorsal hippocampus is essential for long-term spatial memory. J Neurosci 19:3535-3544.

Boulton TG, Nye SH, Robbins DJ, Ip NY, Radziejewska E, Morgenbesser SD, DePinho RA, Panayotatos N, Cobb MH, Yancopoulos GD (1991) ERKs: a family of protein-serine/threonine kinases that are activated and tyrosine phosphorylated in response to insulin and NGF. Cell 65:663-675.

Bozon B, Davis S, Laroche S (2002) Regulated transcription of the immediate-early gene zif268: mechanisms and gene dosage-dependent function in synaptic plasticity and memory formation. Hippocampus 12:570-577.

Bozon B, Kelly A, Josselyn SA, Silva AJ, Davis S, Laroche S (2003) MAPK, CREB, and zif268 are all required for the consolidation of recognition memory. Philos Trans R Soc Lond B Biol Sci 358:805-814.

Changelian PS, Feng P, King TC, Milbrandt J (1989) Structure of the NGFI-A gene and detection of upstream sequences responsible for its transcriptional induction by nerve growth factor. Proc Natl Acad Sci USA 86:377-381.

Clayton DF (2000) The genomic action potential. Neurobiol Learn Mem 74:185-216.

Clifton RK, Nelson MN (1976) Developmental study of habituation in infants: the importance of paradigm, response system, and state. In: Habituation: perspectives from child development, animal behavior, and neurophysiology (Tighe TJ, Leaton RN, eds), pp 159-205. New York: Wiley.

Crow T, Xue-Bian JJ, Siddiqi V, Kang Y, Neary JT (1998) Phosphorylation of mitogen-activated protein kinase by one-trial and multi-trial classical conditioning. J Neurosci 18:3480-3487.

Davis S, Vanhoutte P, Pages C, Caboche J, Laroche S (2000) The MAPK/ ERK cascade targets both Elk-1 and cAMP response element-binding protein to control long-term potentiation-dependent gene expression in the dentate gyrus in vivo. J Neurosci 20:4563-4572.

Davis S, Bozon B, Laroche S (2003) How necessary is the activation of the immediate early gene zif268 in synaptic plasticity and learning? Behav Brain Res 142:17-30.

English JD, Sweatt JD (1996) Activation of p42 mitogen-activated protein kinase in hippocampal long-term potentiation. J Biol Chem 271:24329-24332.

English JD, Sweatt JD (1997) A requirement for the mitogen-activated protein kinase cascade in hippocampal long-term potentiation. J Biol Chem 272:19103-19106.

Favata MF, Horiuchi KY, Manos EJ, Daulerio AJ, Stradley DA, Feeser WS, Van Dyk DE, Pitts WJ, Earl RA, Hobbs F, Copeland RA, Magolda RL, Scherle PA, Trzaskos JM (1998) Identification of a novel inhibitor of mitogen-activated protein kinase kinase. J Biol Chem 273:18623-18632.

Guzowski JF (2002) Insights into immediate-early gene function in hippocampal memory consolidation using antisense oligonucleotide and fluorescent imaging approaches. Hippocampus 12:86-104.

Impey S, Smith DM, Obrietan K, Donahue R, Wade C, Storm DR (1998) Stimulation of cAMP response element (CRE)-mediated transcription during contextual learning. Nat Neurosci 1:595-601.

Izquierdo LA, Viola H, Barros DM, Alonso M, Vianna MR, Furman M, Levi de Stein M, Szapiro G, Rodrigues C, Choi H, Medina JH, Izquierdo I (2001) Novelty enhances retrieval: molecular mechanisms involved in rat hippocampus. Eur J Neurosci 13:1464-1467.

Jarvis ED, Nottebohm F (1997) Motor-driven gene expression. Proc Natl Acad Sci USA 94:4097-4102.

Jin H, Clayton DF (1997) Localized changes in immediate-early gene regulation during sensory and motor learning in zebra finches. Neuron 19:1049-1059.

Kruse AA (2001) Dynamic modulation of an immediate-early gene in the songbird forebrain. PhD thesis, University of Illinois.

Kruse AA, Stripling R, Clayton DF (2000) Minimal experience required for immediate-early gene induction in zebra finch neostriatum. Neurobiol Learn Mem 74:179-184.

Mello CV (2002) Mapping vocal communication pathways in birds with inducible gene expression. J Comp Physiol [A] Neuroethol Sens Neural Behav Physiol 188:943-959.
Mello CV, Clayton DF (1994) Song-induced ZENK gene expression in auditory pathways of songbird brain and its relation to the song control system. J Neurosci 14:6652-6666.

Mello CV, Clayton DF (1995) Differential induction of the ZENK gene in the avian forebrain and song control circuit after metrazole-induced depolarization. J Neurobiol 26:145-161.

Mello CV, Ribeiro S (1998) Zenk protein regulation by song in the brain of songbirds. J Comp Neurol 393:426-438.

Mello CV, Vicario DS, Clayton DF (1992) Song presentation induces gene expression in the songbird forebrain. Proc Natl Acad Sci USA 89:6818-6822.

Mello CV, Nottebohm F, Clayton D (1995) Repeated exposure to one song leads to a rapid and persistent decline in an immediate early gene's response to that song in zebra finch telencephalon. J Neurosci 15:6919-6925.

Morozov A, Muzzio IA, Bourtchouladze R, Van-Strien N, Lapidus K, Yin D, Winder DG, Adams JP, Sweatt JD, Kandel ER (2003) Rap1 couples cAMP signaling to a distinct pool of p42/44MAPK regulating excitability, synaptic plasticity, learning, and memory. Neuron 39:309-325.

Park KHJ, Clayton DF (2002) Influence of restraint and acute isolation on the selectivity of the adult zebra finch zenk gene response to acoustic stimuli. Behav Brain Res 136:185-191.

Pereyra P, Gonzalez Portino E, Maldonado H (2000) Long-lasting and context-specific freezing preference is acquired after spaced repeated presentations of a danger stimulus in the crab Chasmagnathus. Neurobiol Learn Mem 74:119-134.

Perron JC, Bixby JL (1999) Distinct neurite outgrowth signaling pathways converge on ERK activation. Mol Cell Neurosci 13:362-378.

Reiner A, Perkel DJ, Bruce LL, Butler AB, Csillag A, Kuenzel W, Medina L, Paxinos G, Shimizu T, Striedter GF, Wild JM, Ball GF, Durand S, Gunturkun O, Lee DW, Mello CV, Powers A, White SA, Hough GE, Kubikova L, Smulders TV, Wada K, Dugas-Ford J, Husband S, Yamamoto K, Yu J, Siang C, Jarvis ED (2004) Revised nomenclature for avian telencephalon and some related brainstem nuclei. J Comp Neurol 473:377-414.

Ressler KJ, Paschall G, Zhou XL, Davis M (2002) Regulation of synaptic plasticity genes during consolidation of fear conditioning. J Neurosci 22:7892-7902.

Ribeiro S, Mello CV (2000) Gene expression and synaptic plasticity in the auditory forebrain of songbirds. Learn Mem 7:235-243.

Sananbenesi F, Fischer A, Schrick C, Spiess J, Radulovic J (2002) Phosphorylation of hippocampal Erk-1/2, Elk-1, and p90-Rsk-1 during contextual fear conditioning: interactions between Erk-1/2 and Elk-1. Mol Cell Neurosci 21:463-476.

Schafe GE, Atkins CM, Swank MW, Bauer EP, Sweatt JD, LeDoux JE (2000) Activation of ERK/MAP kinase in the amygdala is required for memory consolidation of pavlovian fear conditioning. J Neurosci 20:8177-8187.

Seger R, Ahn NG, Boulton TG, Yancopoulos GD, Panayotatos N, Radziejewska E, Ericsson L, Bratlien RL, Cobb MH, Krebs EG (1991) Microtubuleassociated protein 2 kinases, ERK1 and ERK2, undergo autophosphorylation on both tyrosine and threonine residues: implications for their mechanism of activation. Proc Natl Acad Sci USA 88:6142-6146.

Selcher JC, Weeber EJ, Christian J, Nekrasova T, Landreth GE, Sweatt JD (2003) A role for ERK MAP kinase in physiologic temporal integration in hippocampal area CA1. Learn Mem 10:26-39.

Sgambato V, Pages C, Rogard M, Besson MJ, Caboche J (1998) Extracellular signal-regulated kinase (ERK) controls immediate early gene induction on corticostriatal stimulation. J Neurosci 18:8814-8825.

Sharma SK, Sherff CM, Shobe J, Bagnall MW, Sutton MA, Carew TJ (2003) Differential role of mitogen-activated protein kinase in three distinct phases of memory for sensitization in Aplysia. J Neurosci 23:3899-3907.

Stoddard PK (1996) Vocal recognition of neighbors by territorial passerines. In: Ecology and evolution of acoustic communication in birds (Kroodsma DE, Miller EH, eds), pp 356-374. Ithaca, NY: Cornell UP.

Stopfer M, Chen X, Tai YT, Huang GS, Carew TJ (1996) Site specificity of short-term and long-term habituation in the tail-elicited siphon withdrawal reflex of Aplysia. J Neurosci 16:4923-4932.

Stripling R, Volman SF, Clayton DF (1997) Response modulation in the 
zebra finch neostriatum: relationship to nuclear gene regulation. J Neurosci 17:3883-3893.

Stripling R, Kruse AA, Clayton DF (2001) Development of song responses in the zebra finch caudomedial neostriatum: role of genomic and electrophysiological activities. J Neurobiol 48:163-180.

Stripling R, Milewski L, Kruse AA, Clayton DF (2003) Rapidly learned songdiscrimination without behavioral reinforcement in adult male zebra finches (Taeniopygia guttata). Neurobiol Learn Mem 79:41-50.

Swank MW (2000) Phosphorylation of MAP kinase and CREB in mouse cortex and amygdala during taste aversion learning. NeuroReport 11:1625-1630.

Thompson RF, Spencer WA (1966) Habituation: a model phenomenon for the study of neuronal substrates of behavior. Psychol Rev 173:16-43.

Ying SW, Futter M, Rosenblum K, Webber MJ, Hunt SP, Bliss TV, Bramham CR (2002) Brain-derived neurotrophic factor induces long-term potentiation in intact adult hippocampus: requirement for ERK activation coupled to CREB and upregulation of Arc synthesis. J Neurosci 22:1532-1540.

Yuan L-L, Adams JP, Swank M, Sweatt JD, Johnston D (2002) Protein kinase modulation of dendritic $\mathrm{K}^{+}$channels in hippocampus involves a mitogen-activated protein kinase pathway. J Neurosci 22:4860-4868.

Zann RA (1996) The zebra finch: a synthesis of field and laboratory studies. Oxford: Oxford UP. 